Journal of EST, Volume 2 Nomor 2 Agustus 2016 hal. 56- 64

p-ISSN: 2460-1497

e-ISSN : 2477-3840

\title{
PENGARUH PELAKSANAAN MODEL PEMBELAJARAN KOOPERATIF TIPE THINK PAIR SHARE TERHADAP HASIL BELAJAR IPS SISWA
}

\author{
Andi Fathul Asdar \\ Guru Sekolah Dasar \\ Sekolah Dasar Negeri Gaddong II Kota Makassar \\ andi.fathul.asdar@gmail.com
}

\begin{abstract}
The objective of this research was to describe: 1) Teacher ability in the implementation of cooperative learning Think Pair Share, 2) Ttudent activities in the implementation of cooperative learning Think Pair Share, 3) Tearning result on IPS before and after the implementation of cooperative learning Think Pair Share, 4) learning result on IPS before and after learning process with lecture method, 5) to find out the influence of the implementation of cooperative learning Think Pair Share toward learning result on IPS. The method used was true experiment with pre-test post-test control group design. The population in the study are $4^{\text {th }}$ grade student at SDN Sungguminasa II Somba Opu District Gowa Regency. Samples used are 40 student 20 student each from experiment and comparing group. chosen by simple random sampling. The data obtained from samples were analyzed with descritive and inferensial statistic. The result shows: 1) teacher ability in the implementation of cooperative learning Think Pair Share have increased, 2) student activities in the implementation of cooperative learning Think Pair Share, 3) student learning result who teached by cooperative learning Think Pair Share have increased, 4) student learning result who teached by lecture method have not increased, 5) the implementation of cooperative learning Think Pair Share is influencing toward learning result on IPS in $4^{\text {th }}$ grade student at SDN Sungguminasa II Somba Opu District Gowa Regency.
\end{abstract}

Keyword: Cooperative Learning, Think Pair Share Type, Learning Result

\begin{abstract}
ABSTRAK
Penelitian ini bertujuan untuk: 1) Mengetahui kemampuan guru dalam melaksanakan model pembelajaran kooperatif tipe Think Pair Share, 2) Mengetahui aktivitas siswa dalam pelaksanaan model pembelajaran kooperatif tipe Think Pair Share, 3) Mengetahui hasil belajar IPS sebelum dan sesudah pelaksanaan model pembelajaran kooperatif tipe Think Pair Share, 4) Mengetahui hasil belajar IPS sebelum dan sesudah pelaksanaan pembelajaran dengan metode ceramah, 5) Mengetahui pengaruh pelaksanaan model pembelajaran kooperatif tipe Think Pair Share terhadap hasil belajar IPS. Jenis penelitian yang digunakan adalah true experiment dengan desain penelitian Pre-Test Post-Test Control Group Design. Populasi penelitian ini siswa kelas IV SDN Sungguminasa II Kabupaten Gowa. Sampel yang digunakan dalam penelitian ini adalah 40 siswa yang terdiri dari 20 siswa $I V_{A}$ dan 20 siswa kelas $I V_{B}$, dilakukan dengan teknik simple random sampling. Data dianalisis dengan analisis deskriptif dan statistik inferensial. Hasil penelitian menunjukkan: 1) kemampuan guru dalam pelaksanaan model pembelajaran kooperatif tipe Think Pair Share mengalami peningkatan, 2) aktivitas siswa dalam pelaksanaan model pembelajaran kooperatif tipe Think Pair Share mengalami peningkatan, 3) hasil belajar siswa yang diajar dengan model pembelajaran kooperatif tipe Think Pair Share mengalami peningkatan, 4) hasil belajar siswa yang diajar dengan metode ceramah tidak mengalami peningkatan, 5) terdapat pengaruh positif dan signifikan pelaksanaan pembelajaran dengan tipe Think Pair Share terhadap hasil belajar IPS siswa kelas IV SDN Sungguminasa II Kecamatan Somba Opu Kabupaten Gowa.
\end{abstract}

Kata kunci: Pembelajaran Kooperatif, Tipe Think Pair Share, Hasil Belajar 


\section{PENDAHULUAN}

Mata pelajaran IPS disekolah dasar merupakan perwujudan dari satu pendekatan interdisipliner dari pelajaran ilmu-ilmu sosial. IPS mengkaji seperangkat peristiwa, konsep, dan generalisasi yang berkaitan dengan isu sosial. Melalui mata pelajaran IPS, peserta didik diarahkan untuk dapat menjadi warga Negara Indonesia yang demokratis, dan bertanggung jawab, serta warga dunia yang cinta damai. Mata pelajaran IPS dirancang untuk mengembangkan kemampuan anak didik agar menjadi anggota masyarakat yang memiliki pengetahuan, pemahaman, dan kemampuan analisis terhadap kondisi sosial masyarakat dalam memasuki kehidupan bermasyarakat yang dinamis.

Memperhatikan tujuan yang dikandung dalam mata pelajaran pengetahuan sosial maka seharusnya pembelajaran di sekolah-sekolah merupakan suatu kegiatan yang disenangi, menantang, dan bermakna bagi siswa. Untuk itu, pembelajaran IPS perlu dilaksanakan sebaik mungkin dengan melibatkan siswa secara langsung dalam menelaah dan memahami konsep yang disampaikan oleh guru sehingga materi yang dipelajari dapat diaplikasikan dalam kehidupan sehari-harinya.

Berdasarkan hasil observasi awal yang dilakukan pada tanggal 22 Februari 2016 di SDN Sungguminasa II Kabupaten Gowa, khususnya di kelas IV, guru telah melaksanakan pembelajaran dengan baik. Guru menggunakan berbagai media dan memberi kesempatan pada siswa untuk terlibat aktif dalam pembelajaran, khususnya dalam pembelajaran Matematika dan IPA. Namun dalam pembelajaran IPS, guru cenderung mendikte dengan alasan materi yang diajarkan berbentuk bacaan. Guru memberi penjelasan materi yang ada pada buku pegangan. Penjelasan yang panjang lebar membuat siswa jenuh dan kurang memperhatikan materi yang disampaikan. Ketika guru memberi kesempatan kepada siswa untuk bertanya, tak satupun siswa yang mengajukan pertanyaan. Hal ini dibiarkan oleh guru tanpa memotivasi siswa untuk bertanya. Guru kembali melanjutkan penjelasan lalu memberi tugas yang ada pada buku pegangan.

Pembelajaran IPS yang berisi nilai-nilai sosial sehingga perlu dilakukan suatu upaya untuk mengatasi permasalahan yang ada. Pembelajaran IPS, sebagaimana mata pelajaran lainnya, juga dapat dilaksanakan dengan menerapkan berbagai model pembelajaran. Salah satu model pembelajaran yang dapat diterapkan yakni model Think Pair Share.

Model pembelajaran kooperatif tipe Think Pair Share dikembangkan oleh Frank Lyman dan kawan-kawannya (Lie, 2005) dari Universitas Maryland yang mampu mengubah asumsi bahwa metode resitasi dan diskusi perlu diselenggarakan dalam setting kelompok kelas secara keseluruhan. Model pembelajaran kooperatif tipe Think Pair Share memberikan waktu kepada siswa untuk berpikir dan merespons serta saling bantu satu sama lain. Sebagai contoh, seorang guru baru saja menyelesaikan suatu sajian pendek atau siswa telah selesai membaca suatu tugas. Selanjutnya, guru meminta kepada siswa untuk menyadari secara lebih serius mengenai apa yang telah dijelaskan oleh guru atau apa yang telah dibaca. Dengan demikian model pembelajaran kooperatif tipe Think Pair Share dapat dipilih untuk melibatkan siswa secara keseluruhan.

Model pembelajaran kooperatif tipe Think Pair Share menekankan pada aktivitas siswa secara maksimal untuk mencari dan menemukan jawaban sendiri pada tahap think, menumbuhkan sikap percaya diri dan berani mengeluarkan pendapat serta menghargai pendapat orang lain pada tahap pair dan share. Pada setiap tahap tersebut bukan hanya aktivitas belajar saja yang diharapkan dapat meningkat namun juga diharapkan siswa mendapatkan pembelajaran yang bermakna.

Sanjaya (2009: 44) mengemukakan bahwa "pembelajaran kooperatif merupakan pendekatan pembelajaran yang menekankan adanya kerjasama antar siswa dalam kelompok untuk tujuan belajar". Sementara Asma (2006: 18) berpendapat bahwa "pembelajaran kooperatif merupakan suatu kelompok kecil siswa yang bekerja sebagai sebuah tim untuk menyelesaikan suatu masalah untuk menyelesaikan tugas atau mengerjakan sesuatu untuk mencapai tujuan bersama".

Davidson dan Karoll (Lie, 2005) belajar kooperatif adalah kegiatan yang berlangsung di lingkungan belajar dalam kelompok kecil yang saling berbagi ide-ide dan bekerja secara kolaboratif untuk memecahkan masalah-masalah yang ada dalam tugas mereka. Model pembelajaran kooperatif merupakan model pembelajaran dengan setting kelompokkelompok kecil dengan memperhatikan 
keberagaman anggota kelompok sebagai wadah siswa bekerjasama dan memecahkan suatu masalah melalui interaksi sosial dengan teman sebayanya.

Pengertian Think Pair Share yang dikemukakan oleh Lie (2005: 57) bahwa, Think Pair Share adalah pembelajaran yang memberi siswa kesempatan untuk bekerja sendiri dan bekerjasama dengan orang lain. Arends (Trianto, 2007: 121) menyatakan bahwa Think Pair Share merupakan suatu cara yang efektif untuk membuat variasi suasana pola diskusi kelas. Dengan asumsi bahwa semua resitasi atau diskusi membutuhkan pengaturan untuk mengendalikan kelas secara keseluruhan, dan prosedur yang digunakan dalam Think Pair Share dapat memberi siswa lebih banyak waktu berpikir, untuk merespon dan saling membantu. Guru memperkirakan hanya melengkapi penyajian singkat atau siswa membaca tugas atau situasi yang menjadi tanda tanya. Suyatno (2009: 54) mengatakan bahwa Think Pair Share adalah model pembelajaran kooperatif yang memiliki prosedur ditetapkan secara eksplinsit memberikan waktu lebih banyak kepada siswa untuk memikirkan secara mendalam tentang apa yang dijelaskan atau dialami (berfikir, menjawab, dan saling membantu satu sama lain)".

Secara umum, model Think Pair Share berisi tiga tahapan sebagaimana yang dikemukakan oleh Lie (2005) yaitu: 1) Berpikir (Thinking). Pada tahap ini siswa diminta untuk berpikir secara mandiri mengenai pertanyaan atau masalah yang diajukan. Siswa sebaiknya menuliskan jawaban mereka, sehingga melalui catatan tersebut guru dapat mengetahui jawaban yang harus diperbaiki atau diluruskan diakhir pembelajaran. Dalam menentukan batasan waktu untuk tahapan ini, guru harus mempertimbangkan pengetahuan dasar siswa untuk menjawab pertanyaan yang diberikan, serta jadwal pembelajaran untuk setiap kali pertemuan. Kelebihan dari tahap ini adalah "think time" atau waktu berpikir yang memberikan kesempatan kepada siswa untuk berpikir mengenai jawaban mereka sendiri sebelum pertanyaan tersebut dijawab oleh siswa lain. Selain itu, guru dapat mengurangi masalah dari adanya siswa yang mengobrol, karena setiap siswa memiliki tugas untuk dikerjakan sendiri, 2) Berpasangan (Pairing). Selanjutnya guru meminta kepada siswa untuk berpasangan dan mendiskusikan mengenai apa yang telah dipikirkan. Interaksi selama periode ini dapat menghasilkan jawaban bersama jika suatu pertanyaan telah diajukan atau penyampaian ide bersama jika suatu isu khusus telah diidentitifikasi. Biasanya guru mengizinkan tidak lebih dari 4 atau 5 menit untuk berpasangan, dan 3) Berbagi (Sharing). Pada langkah akhir ini guru meminta pasangan-pasangan tersebut untuk berbagi atau bekerja sama dengan kelas secara keseluruhan mengenai apa yang telah mereka bicarakan. Langkah ini akan menjadi efektif jika guru berkeliling kelas dari pasangan yang satu ke pasangan yang lain, sehingga seperempat atau separuh dari pasangan-pasangan tersebut memperoleh kesempatan untuk melapor.

Belajar merupakan kata yang tidak asing. Bahkan sudah merupakan bagian yang tidak terpisahkan dari setiap aktivitas manusia dalam mengembangkan kehidupannya. Sahabuddin (Haling, 2007: 2) menyatakan bahwa belajar "sebagai suatu proses kegiatan yang menimbulkan kelakuan baru atau merubah kelakuan lama sehingga seseorang lebih mampu memecahkan masalah dan menyesuaikan diri terhadap situasi-situasi yang dihadapi dalam hidupnya". Lebih lanjut, Hamalik (2008: 2) mengemukakan bahwa "belajar adalah suatu perkembangan dari seseorang yang dinyatakan dalam cara bertingkah laku yang baru berkat pengalaman dan latihan". Sementara Slameto (2003: 22) berpendapat bahwa "belajar adalah suatu proses usaha yang dilakukan individu untuk memperoleh suatu perubahan tingkah laku yang baru secara keseluruhan, sebagai hasil pengalaman individu itu sendiri dalam interaksi lingkungan".

Hasil belajar merupakan indikator keberhasilan yang dicapai siswa dalam usaha belajarnya. Hasil adalah istilah yang digunakan menyatakan tingkat keberhasilan yang dicapai seseorang setelah melalui proses belajar. Sudjana (2004: 22) menyebutkan hasil belajar sebagai "kemampuan-kemampuan yang dimiliki siswa setelah menerima pengalaman belajarnya". Selanjutnya Abdurrahman (1994: 37-38) mengatakan bahwa Hasil belajar adalah kemampuan yang diperoleh siswa setelah kegiatan belajar. Belajar itu sendiri merupakan suatu proses dari seseorang yang berusaha untuk memperoleh suatu bentuk perubahan perilaku yang relatif menetap. 
Hasil belajar seseorang dapat dilihat pada perubahan sikap dan tingkah laku. Winkel (2009: 40) menggolongkan kemampuan-kemampuan yang menyebabkan perubahan sikap dan tingkah laku tersebut yaitu Kemampuan kognitif yang meliputi pengetahuan dan pemahaman, kemampuan sensori-motorik yang meliputi keterampilan melakukan rangkaian gerak badan dalam urutan tertentu, dan kemampuan dinamikafektif yang meliputi sikap dan nilai yang meresapi perilaku dan tindakan.

Kosasi Djahiri (Ishak, 2000: 28) menyatakan bahwa IPS adalah merupakan ilmu pengetahuan yang memadukan sejumlah konsep pilihan dari cabang ilmu sosial dan ilmu lainnya serta kemudian diolah berdasarkan prinsipprinsip pendidikan dan didaktif untuk dijadikan program pengajaran pada tingkat persekolahan.

Sapriya, dkk (2006) mengemukakan bahwa secara mendasar pengajaran IPS berkenaan dengan kehidupan manusia yang melibatkan segala tingkah laku dan kebutuhannya. IPS berkenaan dengan cara manusia menggunakan usaha memenuhi kebutuhan materinya, memenuhi kebutuhan budayanya, kebutuhan kejiwaannya, pemanfaatan sumber yang ada dipermukaan bumi, mengatur kesejahteraan dan pemerintahannya, dan lain sebagainya yang mengatur serta mempertahankan kehidupan masyarakat manusia. Leonard (tanpa tahun) dalam Ishak (2000) mengemukakan bahwa IPS menggambarkan interaksi individu atau kelompok dalam masyarakat baik dalam lingkungan mulai dari yang terkecil misalkan keluarga, tetangga, rukun tetangga atau rukun warga, desa / kelurahan, kecamatan, kabupaten, propinsi, negara dan dunia.

Mata pelajaran IPS dirancang untuk mengembangkan pengetahuan, pemahaman, dan kemampuan analisis terhadap kondisi sosial masyarakat dalam memasuki kehidupan bermasyarakat yang dinamis. Dengan demikian, dapat disimpulkan bahwa hasil belajar IPS merupakan perubahan kemampuan kognitif, sikap, dan keterampilan yang diperoleh siswa setelah pembelajaran IPS. Adapun kriteria penilaian hasil belajar IPS yang digunakan mengacu pada kurikulum yang diterapkan di sekolah tempat penelitian dilakukan.

Secara teoretis dapat dikemukakan bahwa tipe Think Pair Share dapat mendorong siswa untuk aktif dalam belajar, bertukar pendapat, dan saling membantu. Dengan demikian, pelaksanaan pembelajaran dengan tipe Think Pair Share dapat mempengaruhi hasil belajar IPS siswa Kelas IV SDN Sungguminasa II Kecamatan Somba Opu Kabupaten Gowa.

Penelitian ini bertujuan: 1) Untuk mengetahui kemampuan guru dalam melaksanakan model pembelajaran kooperatif tipe Think Pair Share, 2) Untuk mengetahui aktivitas siswa dalam pelaksanaan model pembelajaran kooperatif tipe Think Pair Share, 3) Untuk mengetahui hasil belajar IPS sebelum dan sesudah pelaksanaan model pembelajaran kooperatif tipe Think Pair Share, 4) Untuk mengetahui hasil belajar IPS sebelum dan sesudah pelaksanaan pembelajaran dengan metode ceramah, 5) Untuk mengetahui pengaruh pelaksanaan model pembelajaran kooperatif tipe Think Pair Share terhadap hasil belajar IPS.

Hipotesis penelitian ini adalah terdapat perbedaan yang signifikan antara hasil belajar IPS dengan model pembelajaran kooperatif tipe Think Pair Share dan metode ceramah, dimana hasil belajar IPS dengan model pembelajaran kooperatif tipe Think Pair Share lebih baik daripada hasil belajar metode ceramah.

\section{METODE PENELITIAN}

Penelitian ini dirancang untuk mengetahui pengaruh pelaksanaan model pembelajaran kooperatif tipe Think Pair Share terhadap hasil belajar IPS siswa kelas IV SDN Sungguminasa II Kabupaten Gowa. Jenis penelitian yang digunakan adalah true experiment (eksperimen sebenarnya). Desain yang digunakan adalah PreTest Post-Test Control Group Design.

Variabel dalam penelitian ini adalah model pembelajaran kooperatif tipe Think Pair Share sebagai variabel bebas (independen) dan hasil belajar IPS sebagai variabel terikat (dependen). Untuk menghindari perbedaan penafsiran menyangkut variabel dalam penelitian ini, maka variabel tersebut didefenisikan secara operasional yaitu 1) Pelaksanaan model pembelajaran tipe Think Pair Share, yakni proses belajar mengajar di kelas yang terdiri dari tiga bagian utama yaitu berpikir, berpasangan, dan berbagi, dan 2) Hasil belajar IPS, yakni pencapaian siswa dalam belajar IPS yang diukur melalui pretest dan posttest.

Populasi dalam penelitian ini adalah siswa kelas IV SDN Sungguminasa II Kabupaten 
Gowa semester genap tahun ajaran 2015/2016 yang terdiri atas dua kelas dengan jumlah siswa sebanyak 95 orang, 48 siswa di kelas IV $_{\mathrm{A}}$ dan 47 siswa di kelas $\mathrm{IV}_{\mathrm{B}}$.

Sampel yang digunakan dalam penelitian ini adalah 40 siswa yang terdiri dari 20 siswa $\mathrm{IV}_{\mathrm{A}}$ dan 20 siswa kelas $\mathrm{IV}_{\mathrm{B}}$. Pengambilan sampel dilakukan dengan menggunakan teknik simple random sampling. Penentuan kelompok eksperimen dan kelompok kontrol dilakukan dengan mengundi dan hasilnya kelas $\mathrm{IV}_{\mathrm{B}}$ sebagai kelompok eksperimen dan kelas $\operatorname{IV}_{\mathrm{A}}$ sebagai kelompok kontrol.

Pengumpulan data dalam penelitian ini dilakukan dengan menggunakan observasi dan tes. Sebelum tes digunakan, terlebih dulu dilakukan analisis terhadap instrumen soal melalui uji validitas dan uji realibilitas. Validitas konstruk divalidasi oleh ahli dan selanjutnya diujicoba lapangan. Uji coba dilakukan di SDN Bonto Kamase dengan mengambil siswa kelas IV sebanyak 20 siswa. Validitas butir soal diukur dengan menggunakan korelasi Point Biserial. Hasil uji validasi yaitu terdapat 4 butir soal yang tidak valid sehingga jumlah soal yang akan digunakan adalah 26 soal. Uji reliabilitas dilakukan dengan test-retest dan diperoleh hasil bahwa instrumen yang digunakan reliabel.

Tabel 4.1 Hasil Observasi Aktivitas Guru dalam Menerapkan Model Pembelajaran Kooperatif Tipe Think Pair Share

\begin{tabular}{ccccccc}
\hline \multirow{2}{*}{ Skala } & \multicolumn{5}{c}{ Pertemuan ke- } & \multirow{2}{*}{ Kategori } \\
\cline { 2 - 6 } & $\mathbf{1}$ & $\mathbf{2}$ & $\mathbf{3}$ & $\mathbf{4}$ & $\mathbf{5}$ & \\
\hline $17-20$ & & & & & 18 & Sangat Tinggi \\
$13-16$ & & & 13 & 16 & & Tinggi \\
$9-12$ & & 11 & & & & Cukup \\
$5-8$ & 8 & & & & & Rendah \\
$0-4$ & & & & & & Sangat Rendah \\
\hline
\end{tabular}

Hasil yang diperoleh menunjukkan kemampuan guru dalam melaksanakan pembelajaran kooperatif tipe Think Pair Share meningkat dari kategori rendah pada pertemuan pertama menjadi kategori cukup pada pertemuan kedua. Pertemuan ketiga dan keempat aktivitas guru berada pada kategori tinggi dan pada pertemuan kelima aktivitas guru berada pada kategori sangat tinggi.

2. Gambaran aktivitas siswa dalam pelaksanaan pembelajaran model kooperatif tipe Think Pair Share

Pedoman observasi memuat 20 item. Setiap item yang terlaksana dicentang kemudian dijumlahkan. Hasil observasi dapat dilihat pada Tabel 4.2 berikut: 
Tabel 4.2 Hasil Observasi Aktivitas Siswa dalam Pembelajaran Model Kooperatif Tipe Think Pair Share

\begin{tabular}{ccccccc}
\hline \multirow{2}{*}{ Skala } & \multicolumn{5}{c}{ Pertemuan ke- } & \multirow{2}{*}{ Kategori } \\
\cline { 2 - 6 } & $\mathbf{1}$ & $\mathbf{2}$ & $\mathbf{3}$ & $\mathbf{4}$ & $\mathbf{5}$ & \\
\hline $17-20$ & & & & & & Sangat Tinggi \\
$13-16$ & & & & 13 & 15 & Tinggi \\
$9-12$ & & 10 & 12 & & & Cukup \\
$5-8$ & 7 & & & & & Rendah \\
$0-4$ & & & & & & Sangat Rendah \\
\hline
\end{tabular}

Hasil yang diperoleh menunjukkan aktivitas siswa meningkat dari kategori rendah pada pertemuan pertama menjadi kategori cukup pada pertemuan kedua dan ketiga. Pada pertemuan keempat dan kelima aktivitas siswa berada pada kategori tinggi.

3. Gambaran hasil belajar siswa sebelum dan sesudah pelaksanaan model pembelajaran kooperatif tipe Think Pair Share

Tes yang digunakan berisi 26 soal. Hasil pretest dan posttest kelompok eksperimen dapat dilihat pada Tabel 4.3 berikut:

Tabel 4.3 Distribusi Frekuensi Hasil Belajar Siswa Kelompok Eksperimen

\begin{tabular}{ccccccc}
\hline \multirow{2}{*}{ No } & \multirow{2}{*}{ Skala } & \multicolumn{2}{c}{ Pre Test } & \multicolumn{2}{c}{ Post Test } & \multirow{2}{*}{ Kategori } \\
\cline { 2 - 6 } & & $\mathbf{F}$ & $\mathbf{\%}$ & $\mathbf{F}$ & $\mathbf{\%}$ & \\
\hline 1. & $21-26$ & 0 & 0 & 16 & $80 \%$ & Sangat Tinggi \\
2. & $16-20$ & 2 & $10 \%$ & 4 & $20 \%$ & Tinggi \\
3. & $11-15$ & 17 & $85 \%$ & 0 & 0 & Cukup \\
4. & $6-10$ & 1 & $5 \%$ & 0 & 0 & Rendah \\
5. & $0-5$ & 0 & 0 & 0 & 0 & Sangat Rendah \\
\hline & Jumlah & 20 & $100 \%$ & 20 & $100 \%$ & \\
\hline
\end{tabular}

Hasil yang diperoleh menunjukkan bahwa terdapat perbedaan yang signifikan pada hasil belajar siswa kelompok eksperimen sebelum dan sesudah pembelajaran IPS dengan model pembelajaran tipe Think Pair Share.

4. Gambaran hasil belajar siswa sebelum dan sesudah pembelajaran dengan metode ceramah

Tes yang digunakan berisi 26 soal. Hasil pretest dan posttest kelompok kontrol dapat dilihat pada Tabel 4.4 berikut:

Tabel 4.4 Distribusi Frekuensi Hasil Belajar Siswa Kelompok Kontrol

\begin{tabular}{ccccccc}
\hline \multirow{2}{*}{ No } & \multirow{2}{*}{ Skala } & \multicolumn{2}{c}{ Pre Test } & \multicolumn{2}{c}{ Post Test } & \multirow{2}{*}{ Kategori } \\
\cline { 2 - 6 } & & $\mathbf{F}$ & $\mathbf{\%}$ & $\mathbf{F}$ & $\mathbf{\%}$ & \\
\hline 1. & $21-26$ & 0 & 0 & 0 & 0 & Sangat Tinggi \\
2. & $16-20$ & 1 & $5 \%$ & 3 & $15 \%$ & Tinggi \\
3. & $11-15$ & 14 & $70 \%$ & 17 & $85 \%$ & Cukup \\
4. & $6-10$ & 5 & $25 \%$ & 0 & 0 & Rendah \\
5. & $0-5$ & 0 & 0 & 0 & 0 & Sangat Rendah \\
\hline & Jumlah & 20 & $100 \%$ & 20 & $100 \%$ & \\
\hline
\end{tabular}

Hasil yang diperoleh menunjukkan bahwa tidak ada perbedaan yang signifikan pada hasil belajar siswa kelompok kontrol sebelum dan sesudah pembelajaran IPS dengan metode ceramah. 
5. Pengaruh model pembelajaran tipe Think Pair Share terhadap hasil belajar IPS siswa kelas IV SDN Sungguminasa II

Pengujian hipotesis dilakukan dengan mencari rata-rata dari nilai selisih atau gainscore hasil pretest dan posttest pada kelompok eksperimen dan kelompok kontrol. Perbandingan gainscore kelompok eksperimen dan kelompok kontrol diaplikasikan dengan menggunakan uji t dua sampel tidak berpasangan (independent sample t-test) untuk mengetahui pengaruh model pembelajaran tipe Think Pair Share terhadap hasil belajar IPS. Hasil uji gainscore dapat dilihat pada Tabel 4.5 berikut:

Tabel 4.5 Hasil Uji Gainscore pada Independet Samples T-Test

\begin{tabular}{|ll|r|r|r|c|}
\hline \multicolumn{1}{|c|}{ Group Statistics } \\
\hline Grup & $\mathrm{N}$ & Mean & $\begin{array}{c}\text { Std. } \\
\text { Deviation }\end{array}$ & $\begin{array}{c}\text { Std. Error } \\
\text { Mean }\end{array}$ \\
\hline & Kontrol & 20 & 1.8500 & 2.34577 & .52453 \\
& Eksperimen & 20 & 9.4500 & 1.95946 & .43815 \\
\hline
\end{tabular}

\section{Independent Samples T-Test}

\begin{tabular}{|c|c|c|c|c|c|c|c|c|c|c|}
\hline & \multicolumn{2}{|c|}{\begin{tabular}{c|} 
Levene's \\
Test for \\
Equality of \\
Variances \\
\end{tabular}} & \multicolumn{7}{|c|}{$\mathrm{t}$-test for Equality of Means } \\
\hline & & \multirow[b]{2}{*}{$\mathrm{F}$} & \multirow[b]{2}{*}{ Sig. } & \multirow[b]{2}{*}{$\mathrm{t}$} & \multirow[b]{2}{*}{ Df } & \multirow[b]{2}{*}{$\begin{array}{l}\text { Sig. (2- } \\
\text { tailed) }\end{array}$} & \multirow[b]{2}{*}{$\begin{array}{c}\text { Mean } \\
\text { Difference }\end{array}$} & \multirow[b]{2}{*}{$\begin{array}{l}\text { Std. Error } \\
\text { Difference }\end{array}$} & \multicolumn{2}{|c|}{$\begin{array}{l}95 \% \\
\text { Confidence } \\
\text { Interval of the } \\
\text { Difference }\end{array}$} \\
\hline & & & & & & & & & Lower & Upper \\
\hline \multirow[t]{2}{*}{$\begin{array}{l}\text { Hasil } \\
\text { Belajar } \\
\text { IPS }\end{array}$} & $\begin{array}{l}\text { Equal } \\
\text { variances } \\
\text { assumed }\end{array}$ & 1.103 & .300 & -14.113 & 38 & .000 & -8.65000 & .613 & -9.891 & -7.409 \\
\hline & $\begin{array}{l}\text { Equal } \\
\text { variances not } \\
\text { assumed }\end{array}$ & & & -14.113 & 35.920 & .000 & -8.65000 & .613 & -9.893 & -7.407 \\
\hline
\end{tabular}

Nilai $t_{\text {hitung }}$ yang diperoleh adalah 14,113 dengan nilai Sig. (2-tailed) sebesar 0,000 yang berarti pengaruh yang diperoleh adalah signifikan. Nilai didistribusikan dengan $\alpha=0,05$ dan derajat kebebasan $(\mathrm{dk}=20-2=18)$. Nilai $\alpha$ dibagi 2 menjadi 0,025 sehingga diperoleh $t_{\text {tabel }}$ pada uji dua pihak yaitu 2,552. Dengan demikian diperoleh hasil $t_{\text {hitung }}>t_{\text {tabel }}$ yakni 14,113 $>2,552$ yang berarti hipotesis diterima. Dapat dikemukakan bahwa terdapat perbedaan yang signifikan antara hasil belajar IPS dengan model pembelajaran kooperatif tipe Think Pair Share dan metode ceramah, dimana hasil belajar IPS dengan model pembelajaran kooperatif tipe Think Pair Share lebih baik daripada hasil belajar metode ceramah. Dengan demikian dapat disimpulkan bahwa terdapat pengaruh positif yang signifikan penggunaan model pembelajaran kooperatif tipe Think Pair Share terhadap hasil belajar IPS siswa kelas IV SDN Sungguminasa II Kecamatan Somba Opu Kabupaten Gowa.

\section{Pembahasan}

Model pembelajaran tipe Think Pair Share memberi kesempatan pada siswa untuk membangun pengetahuannya. Melalui tahap berpikir, siswa menggunakan pengetahuan awal yang mereka miliki dan mengembangkannya dengan membentuk pendapat sendiri. Pada tahap berpasangan, siswa belajar bekerjasama. Hal ini lebih memudahkan siswa karena mereka lebih leluasa dalam mengemukakan pendapat pada temannya sendiri sehingga mereka saling 
membelajarkan. Pada tahap berbagi, siswa belajar menyatukan pendapatnya dengan pendapat temannya. Hal ini membantu mereka bertukar informasi dan mencari jawaban yang tepat terhadap tugas yang diberikan. Raditya, dkk (2015) dari hasil penelitiannya mengemukakan bahwa siswa yang diajar dengan menggunakan model pembelajaran tipe Think Pair Share memiliki hasil belajar yang lebih tinggi dibandingkan siswa yang diajar dengan pembelajaran konvensional. Melalui tahap berpikir, berpasangan, dan berbagi siswa lebih menguasai materi yang diajarkan sehingga hasil belajar siswa meningkat.

Keaktifan siswa mengikuti pelajaran pada kelompok kontrol mendorong siswa menguasai materi lebih cepat. Hal ini berdampak pada peningkatan hasil belajar siswa pada posttest. Sebaliknya pada kelompok kontrol, hasil belajar siswa tidak menunjukkan peningkatan yang signifikan. Siswa kurang menguasai materi dengan baik. Dalam proses pembelajaran, siswa cenderung pasif disebabkan pembelajaran didominasi oleh guru. Guru memberikan penjelasan materi dan sesekali melakukan tanya jawab. Setelah itu siswa lalu diberi tugas yang ada pada buku pegangan. Astutik (2012) mengemukakan bahwa siswa yang tidak aktif atau pasif dalam proses pembelajaran kurang menguasai materi yang diajarkan sehingga hasil belajar yang diperoleh tidak mengalami peningkatan yang signifikan dibandingkan dengan siswa pada pembelajaran yang menggunakan strategi learning centre atau pembelajaran berpusat pada siswa.

Pembelajaran dengan metode ceramah pada kelompok kontrol membuat siswa kurang tertarik mengikuti pelajaran. Siswa terus menerus mendengar penjelasan guru yang menimbulkan rasa jenuh pada siswa. Siswa tidak lagi antusias mengikuti proses pembelajaran, hanya mengikuti apa yang dikatakan guru. Kesempatan untuk membangun sendiri pengetahuan mereka tidak diberikan. Siswa tidak berbagi pendapat sehingga ide atau pikiran mereka hanya tersimpan dalam benak mereka. Tidak ada pertukaran informasi sesama siswa sehingga kemampuan berpikir mereka tidak berkembang yang membuat siswa tidak menguasai materi dengan baik. Pada akhirnya, hasil belajar siswa juga tidak mengalami peningkatan sebagaimana yang terjadi pada kelompok eksperimen.
Proses pembelajaran yang berbeda akan memberi hasil yang berbeda. Siswa pada kelompok eksperimen yang diajar dengan model pembelajaran tipe Think Pair Share lebih menguasai materi dibandingkan dengan siswa kelompok kontrol yang diajar dengan metode ceramah. Dalam model ini, siswa memiliki banyak waktu yang memungkinkan siswa untuk berbagi dan saling membantu satu sama lain sebagaimana yang dikemukakan oleh Lie (2005) bahwa model pembelajaran tipe Think Pair Share memberikan waktu kepada siswa untuk merefleksikan isi materi pelajaran serta melatih mengeluarkan pendapat sebelum berbagi dengan kelompok kecil atau kelas secara keseluruhan. Hal ini membantu siswa menguasai materi dengan lebih baik yang berdampak pada hasil belajar. Rata-rata hasil belajar yang dicapai oleh kelompok eksperimen dan kelompok kontrol menunjukkan bahwa hasil belajar siswa pada kelompok eksperimen lebih tinggi daripada siswa pada kelompok kontrol. Dengan kata lain model pembelajaran tipe Think Pair Share memberi pengaruh pada hasil belajar siswa.

\section{SIMPULAN DAN SARAN}

Berdasarkan hasil penelitian yang diperoleh, maka kesimpulan yang dapat ditarik, yaitu:

1. Aktivitas guru meningkat dari kategori rendah pada pertemuan pertama menjadi kategori cukup pada pertemuan kedua. Pertemuan ketiga dan keempat aktivitas guru berada pada kategori tinggi dan pada pertemuan kelima aktivitas guru berada pada kategori sangat tinggi.

2. Aktivitas siswa meningkat dari kategori rendah pada pertemuan pertama menjadi kategori cukup pada pertemuan kedua dan ketiga. Pada pertemuan keempat dan kelima aktivitas siswa berada pada kategori tinggi.

3. Hasil belajar siswa pada kelompok eksperimen setelah diajar dengan model pembelajaran tipe Think Pair Share mengalami peningkatan yang signifikan. Pada pretest hasil belajar siswa berada pada kategori rendah, cukup, dan tinggi meningkat pada posttest dengan kategori tinggi dan sangat tinggi.

4. Hasil belajar siswa pada kelompok kontrol setelah diajar dengan metode ceramah tidak menunjukkan peningkatan yang signifikan. 
Pada pretest hasil belajar siswa berada pada kategori rendah, cukup, dan tinggi meningkat pada posttest dengan kategori cukup dan tinggi.

5. Terdapat pengaruh positif dan signifikan pelaksanaan pembelajaran dengan tipe Think Pair Share terhadap hasil belajar IPS siswa kelas IV SDN Sungguminasa II Kecamatan Somba Opu Kabupaten Gowa.

Berdasarkan dari hasil penelitian, maka beberapa saran penulis ditujukan kepada:

1. Bagi Kepala Sekolah, hendaknya mengupayakan agar guru-guru menerapkan berbagai model pembelajaran dalam mengajar di kelas.

2. Bagi guru, hendaknya mengembangkan kemampuannya dalam menguasai model pembelajaran kooperatif tipe Think Pair Share yang dapat diterapkan sesuai dengan permasalahan yang muncul dalam pembelajaran sehari-hari.

3. Bagi peneliti lainnya, hendaknya dapat mengkaji lebih lanjut tentang pengaruh pelaksanaan model pembelajaran kooperatif tipe Think Pair Share terhadap hasil belajar siswa.

\section{DAFTAR RUJUKAN}

Abdurrahman. 1994. Pengelolaan Pengajaran. Ujung Pandang: Bintang Selatan.

Asma, Nur. 2006. Model Pembelajaran Kooperatif. Jakarta: Depdiknas.

Astutik, Tri. 2012. Meningkatkan Hasil Belajar Siswa dengan Model Siklus Belajar (Learning Cycle 5E) Berbasis Eksperimen pada Pembelajaran Sains di SDN Patrang I Jember. Jurnal Ilmu Pendidikan Sekolah Dasar, 1 (2).

Haling, Abdul. 2007. Belajar dan Pembelajaran. Makassar: Badan Penerbit UNM.

Hamalik, Oemar. 2008. Prose Belajar Mengajar. Jakarta: Bumi Aksara.

Ishak. 2000. Pendidikan IPS di SD. Jakarta : Universitas Terbuka.

Lie, Anita. 2005.Cooperatif Learning Memperaktekkan Cooperative Learning Di Ruang-Ruang Kelas. Jakarta. PT Gramedia Widiasarana Indonesia

Raditya, I Wayan, dkk. 2015. Pengaruh Model Pembelajaran Kooperatif Tipe Think Pair Share (TPS) terhadap Hasil Belajar
IPA Siswa Kelas VI SD Gugus Letda Made Putra Kecamatan Denpasar Utara Tahun Ajaran 2014/2015. e-Journal PGSD Universitas Pendidikan Ganesha, $3(1)$.

Sanjaya, Wina. 2009. Strategi Pembelajaran: Berorientasi Standar Proses Pendidikan. Jakarta: Prenada Media Group.

Sapriya, dkk. 2006. Konsep Dasar IPS. Bandung: UPI PRESS.

Slameto. 2003. Belajar dan Faktor-Faktor yang Mempengaruhinya. Jakarta: Rineka Cipta.

Sudjana, Nana. 2004. Penilaian Hasil Proses Belajar Mengajar. Bandung: Remaja Rosdakarya.

Suyatno. 2009. Menjelajah Pembelajaran Inovatif. Surabya: Masmedia Buana Pustaka.

Trianto. 2007. Model-model Pembelajaran Inovatif Berorientasi Konstruktivistik. Jakarta: Cerdas Pustaka Publisher.

Winkel, W.S. 2009. Psikologi Pengajaran. Jakarta: Grasindo. 